\title{
Metal reduction at cold temperatures by Shewanella isolates from various marine environments
}

\author{
Raymond D. Stapleton Jr. ${ }^{1,4}$, Zakee L. Sabree ${ }^{1,5}$, Anthony V. Palumbo ${ }^{1, *}$, \\ Craig L. Moyer ${ }^{2}$, Allan H. Devol ${ }^{3}$, Yul Roh ${ }^{1}$, Jizhong Zhou ${ }^{1}$ \\ ${ }^{1}$ Environmental Sciences Division, Oak Ridge National Laboratory, Oak Ridge, Tennessee 37831-6038, USA \\ ${ }^{2}$ Biology Department, Western Washington University, MS \#9160, Bellingham, Washington 98225-9160, USA \\ ${ }^{3}$ School of Oceanography, The University of Washington, Seattle, Washington 98295, USA \\ ${ }^{4}$ Present address: Technical Operations, Merck \& Co., Inc., Elkton, Virginia 22827, USA \\ ${ }^{5}$ Present address: Department of Plant Pathology, University of Wisconsin, Madison, Wisconsin 52706, USA
}

\begin{abstract}
Members of the genus Shewanella capable of reducing metals and forming minerals under cold-temperature conditions were isolated from 3 distinct marine habitats (the coast of Washington State, the Puget Sound, and an iron-rich microbial mat off Hawaii). Cultures of microorganisms were isolated at $8^{\circ} \mathrm{C}$ on nutrient agar medium prepared in artificial seawater. Isolates in this study could use a wide variety of electron acceptors such as oxygen, nitrate, and metals, and reduce various metals coupled to the oxidation of several organic acids, glucose or hydrogen at temperatures down to $0^{\circ} \mathrm{C}$. Akaganeite was reduced to either magnetite or siderite, depending on the test conditions. The geochemical profiles at the sample sites from which these strains were isolated spanned a temperature range of 1.8 to $11^{\circ} \mathrm{C}$, and all showed active oxygen and nitrate reduction as well as metal reduction. This confirms previous reports that sediment microorganisms participating in biogeochemical cycles remain active at low temperatures.
\end{abstract}

KEY WORDS: Biogeochemistry · Geomicrobiology $\cdot$ Iron reduction $\cdot$ Cobalt reduction · Magneite

\section{INTRODUCTION}

Marine sediments have long been known as sites of active biogeochemical processes, including nitrate reduction, manganese/iron reduction, sulfate reduction and methanogenesis. Sedimentary biogeochemical activities have been documented to continue at temperatures around $0^{\circ} \mathrm{C}$ (Kostka et al. 1999). Organic matter mineralization by dissimilatory iron-reducing bacteria (DIRB) has been shown to be important in marine environments (Lovley \& Phillips 1988). Fe- and Mn-oxides may often represent the electron acceptors available at the highest concentrations in marine sediments (Canfield et al. 1993, Aller et al. 1998, Thamdrup et al. 2000). Early reports demonstrated that the oxidation of organic material could be coupled with the reduction of Fe(III) (Sørenson 1982, Lovley \& Phillips 1986). Sediment magnetism has also been linked to iron cycling in marine environments (Kostka \& Nealson 1995).

Sedimentary microbial communities are complex (Bowman et al. 2000). The recovery of pure cultures for laboratory experimentation is a tedious process, often fraught with biases. However, pure cultures of microorganisms isolated from specific environments provide laboratory models for investigators to examine. Since most of the global marine environment exists at low temperatures, recovery of microbes capable of reducing metals, such as iron and cobalt, at low temperatures would provide useful models to further the understanding of sedimentary biogeochemistry. 
While their quantitative importance in marine sediments and water columns is not well understood, members of the genus Shewanella are commonly encountered in marine environments (Perry et al. 1993, Thamdrup et al. 2000, Brettar et al. 2002). These isolates have provided useful models for laboratory investigations on metal reduction (Nealson \& Saffarini 1994, Kostka \& Nealson 1995), food spoilage, barophilic growth (Kato \& Nogi 2001) and, more recently, psychrophilic enzymes (Irwin et al. 2001a,b). The present study describes the isolation of members of the genus Shewanella from 3 marine environments. Specifically, strains W3-6-1 and PS-7 were used as models to investigate microbial metal reduction and mineral formation at low temperatures.

\section{MATERIALS AND METHODS}

Site description and sampling. Marine sediment samples were collected from a transect off the coast of Washington State (USA), at 2 locations in Puget Sound (USA) and from an iron-rich microbial mat associated with the Naha Vents on the South Rift of Loihi Seamount near Hawaii. With the exception of the vent sites, sediments were collected by box core sampling. The microbial mat sample was collected during DSRV Pisces V dive number 342 (Emerson \& Moyer 2002). Each box core was sub-cored for sectioning using 7.5 and $10 \mathrm{~cm}$ cast-acrylic core tubes. Core sectioning took place within approximately $1 \mathrm{~h}$ of coring in a glove-box at $\sim 5^{\circ} \mathrm{C}$ in a $\mathrm{N}_{2}$ atmosphere. Cores were stored at $\sim 5^{\circ} \mathrm{C}$ to minimize effects due to warming. Details of sample location, including geographic coordinates, are listed in Table 1.
The geochemistry of the sediments was inferred from sediment pore-water distributions. Pore-water was separated from the sediments by centrifugation at $\sim 7000 \mathrm{rpm}(>10000 \times g)$ for $20 \mathrm{~min}$; supernatants were filtered through pre-combusted GF-F filters before sub-sampling for various analyses. Whole-core squeezing at $\sim 5^{\circ} \mathrm{C}$ was used to obtain high-resolution pore-water profiles of $\mathrm{O}_{2}$ and $\mathrm{NO}_{3}^{-}$(Bender et al. 1987). Pore-water samples were expressed through an inline, radiometer-style oxygen electrode before collection for nutrient analysis (Brandes \& Devol 1995). The oxygen electrode was standardized against air-saturated seawater and $\mathrm{N}_{2}$-purged seawater.

For the Naha Vents sample, temperature was measured using a thermistor probe on the submersible, while for the Puget Sound and coast of Washington State sites the bottom water temperature was determined with a SeaBird CTD.

Bacterial isolation. Anaerobic culturing techniques were used throughout the study following standard protocols (Hungate 1969, Miller \& Wolin 1974). The culture medium ( $\mathrm{g} \mathrm{l}^{-1} \mathrm{dH}_{2} \mathrm{O}$ : sodium chloride, 30.0; sodium bicarbonate, 2.5; MOPS (3-\{N-morpholino\} propanesulfonic acid), 2.0; ammonium chloride, 1.0; yeast extract, 0.5 ; magnesium chloride heptahydrate, 0.2; calcium chloride dihydrate, 0.1 ; trace vitamins and minerals; Phelps et al. 1989) was boiled and prepared under an anaerobic mixed gas atmosphere of $\mathrm{N}_{2} / \mathrm{CO}_{2}$ $(80 / 20 \%)$ or $\mathrm{H}_{2} / \mathrm{CO}_{2}(80 / 20 \%)$. The medium was cooled under the mixed gas atmosphere, dispensed into anaerobic pressure tubes, capped with butyl rubber stoppers, and autoclaved. Stocks of electron donors, electron acceptors, and $\mathrm{pH}$ adjustment reagents were sterilized individually, and then added to the autoclaved basal medium as required.

Table 1. Sources and growth characteristics at different temperatures of bacterial isolates described in this study. Sample depth: depth (m) of water column over sediment location where core was recovered; Core depth: depth $(\mathrm{cm})$ within a sample core from which the sediment sample was recovered. PMS: Pacific marine sediment; PS: Puget Sound; nd: not determined or not applicable

\begin{tabular}{|c|c|c|c|c|c|c|c|c|}
\hline Isolate & Origin & Location & $\begin{array}{c}\text { In situ temp. } \\
\left({ }^{\circ} \mathrm{C}\right)\end{array}$ & $\begin{array}{c}\text { Sample } \\
\text { depth }\end{array}$ & $\begin{array}{l}\text { Core } \\
\text { depth }\end{array}$ & $\begin{array}{l}\text { Growth } \\
\text { at } 0^{\circ} \mathrm{C}\end{array}$ & $\begin{array}{l}\text { Growth } \\
\text { at } 37^{\circ} \mathrm{C}\end{array}$ & $\begin{array}{l}\text { Optimal growth } \\
\text { range }\left({ }^{\circ} \mathrm{C}\right)\end{array}$ \\
\hline W3-4-1 & PMS Stn 307 & Lat $46^{\circ} 26^{\prime} 61^{\prime \prime}$, Long $124^{\circ} 47^{\prime} 22^{\prime \prime}$ & 3.4 & 997 & $5-6$ & Yes & No & $15-18$ \\
\hline W3-6-1 & PMS Stn 307 & Lat 46.26.61 Long 124.47.22 & 3.4 & 997 & $9-10$ & Yes & No & $15-18$ \\
\hline W3-7-1 & PMS Stn 304 & Lat 46.45.05 Long 126.00.58 & 1.8 & 2530 & $0.5-1$ & Yes & No & $15-18$ \\
\hline W3-7-2 & PMS Stn 304 & Lat 46.45.05 Long 126.00.58 & 1.8 & 2530 & $0.5-1$ & Yes & No & $14-17$ \\
\hline W3-11-1 & PMS Stn 301 & Lat 46.48.60 Long 124.37.20 & 8.1 & 119 & $3-4$ & Yes & No & $15-18$ \\
\hline W3-11-2 & PMS Stn 301 & Lat 46.48.60 Long 124.37.20 & 8.1 & 119 & $3-4$ & Yes & No & $14-17$ \\
\hline W3-14-2 & PMS Stn 301 & Lat 46.48.63 Long 124.37.23 & 8.1 & 119 & $7-8$ & Yes & No & $15-18$ \\
\hline PV-4 & Naha Vent mat & & 11.0 & nd & nd & Yes & Yes & $\geq 37^{\mathrm{a}}$ \\
\hline PS-3 & PS sediments & Lat 47.43.5 Long 122.23.9 & 8.1 & 220 & nd & Yes & No & $17-20$ \\
\hline PS-5 & PS sediments & Lat 47.43.5 Long 122.23.9 & 8.1 & 220 & nd & Yes & No & $14-17$ \\
\hline PS-7 & PS sediments & Lat 47.43.5 Long 122.23.9 & 8.1 & 220 & nd & Yes & No & $17-20$ \\
\hline
\end{tabular}


Enrichment cultures were initiated using Fe(III)-citrate $(20 \mathrm{mM})$ and either acetate $(10 \mathrm{mM})$, formate (10 mM), pyruvate (10 mM), or hydrogen $(80 / 20 \%$ hydrogen/carbon dioxide mix), and incubated at $8^{\circ} \mathrm{C}$ in the dark (Zhang et al. 1999). Pure cultures of microorganisms were obtained by spread-plating the enrichment cultures on nutrient agar medium prepared in artificial seawater $\left(\mathrm{g} \mathrm{l}^{-1} \mathrm{dH}_{2} \mathrm{O}\right.$ : sodium chloride, 30.0; magnesium sulfate heptahydrate, 6.0; calcium chloride dihydrate, 1.0; potassium chloride, 1.0; potassium nitrate, 0.5 ; nutrient agar, 23.0 ; $\mathrm{pH} 7.2$ ). The plates were incubated aerobically at $8^{\circ} \mathrm{C}$. Individual colonies were transferred at least 4 times prior to assessing the culture purity by either Enterobacterial Repetitive Intergenic Consensus (ERIC)-PCR or Repetitive Extragenic Palindromic (REP)-PCR (de Bruijn 1992). Once a culture was determined to be pure, it was evaluated for its ability to reduce ferric iron. Cultures of freshly isolated bacteria were maintained in the dark at $8^{\circ} \mathrm{C}$ in $9.0 \mathrm{ml}$ medium with ferric citrate (20 $\mathrm{mM})$ as the electron acceptor and either lactate (10 mM) or hydrogen as the electron donor.

Isolates recovered from Pacific Ocean sediments were given the prefix W3, followed by an enrichment culture number, and then an isolate number. For example, isolate W3-6-1 was isolated from enrichment culture 6 and it was the first organism recovered. Isolates recovered from the Pacific vent iron-rich mat sample were given the prefix PV, and bacteria from Puget Sound sediments were given the prefix with PS (Table 1).

Phylogenetic analyses of bacterial isolates. Genomic DNA was recovered from the isolates as described previously (Zhou et al. 1995). SSU rRNA genes were amplified from genomic DNA using modified primers fD1 and rP1 (Weisberg et al. 1991, Zhou et al.
1995). Amplification, sequencing, and sequence analysis were performed as previously described (Smith et al. 1994, Strunk et al. 1996, Zhou et al. 1997, 2001).

Physiological and analytical analyses. The ability of the pure cultures to use alternate electron acceptors and electron donors was examined by visually monitoring growth (e.g. changes in culture turbidity) or reduction (e.g. changes in medium color) in anaerobic medium (Coates et al. 1998a). Potential electron donors (Table 1) were evaluated in anaerobic medium containing $20 \mu \mathrm{M}$ Fe(III)-citrate at concentrations of $10 \mu \mathrm{M}$ (lactate, formate, acetate, pyruvate, succinate, and citrate) except for glycerol $(5 \mu \mathrm{M})$, buyrate $(5 \mu \mathrm{M})$, toluene $(1 \mu \mathrm{M})$, and hydrogen (1 atm in the headspace). Potential electron acceptors (Table 2) were evaluated individually at concentrations of 0.5 to $70 \mu \mathrm{M}$ (Table 2) in anaerobic basal medium with $10 \mu \mathrm{M}$ lactate. Control tubes without cells were monitored in all experiments. Studies of the effects of sodium chloride concentration on $\mathrm{Fe}(\mathrm{III})$-citrate $(20 \mathrm{mM})$ reduction were performed in the basal anaerobic medium amended with $10 \mathrm{mM}$ lactate.

Growth of the isolates at various temperatures was evaluated aerobically in nutrient broth medium with artificial seawater. The number of generations was calculated following the equation by Prescott et al. (1990). Cell enumeration was performed using fluorescence microscopy (Hobbie et al. 1977). HClextractable $\mathrm{Fe}(\mathrm{II})$ was evaluated using ferrozine (Zhang et al. 1996). Reduction of Co(III) to Co(II) was evaluated with a spectrophotometer by measuring absorbance at $535 \mathrm{~nm}$ (Zhang et al. 1996). Depletion of nitrate was measured using the Szechrome Reagent following manufacturer's instructions (Polysciences). Evolution of $\mathrm{N}_{2} \mathrm{O}$ gas was performed by gas chromatography.

Table 2. Additional growth characteristics of bacterial isolates described in this study. No isolates were capable of using butyrate, succinate, or citrate. Only the Puget Sound isolates were tested for the ability to use toluene and glycerol and none of them were able to utilize these compounds. Standard set: all used oxygen (air in headspace), Fe(III) citrate at 20 mM, Fe(III) EDTA at 10 mM, akaganeite at $70 \mathrm{mM}, \mathrm{Mn}\left(\mathrm{IV}\right.$ ) at $20 \mathrm{mM}$ (as amorphous manganese oxide-MnO${ }_{2}$ ), Co(III)-EDTA at $1 \mathrm{mM}$; none were able to use $\mathrm{Cr}(\mathrm{IV})$ at $0.5 \mathrm{mM}$ (as the potassium salt). Nitrate support weak growth. No isolates grew at $10 \%$ salt

\begin{tabular}{|c|c|c|c|}
\hline Isolate & Electron donors & Electron acceptors & Salinity range $(\%)$ \\
\hline W3-4-1 & Lactate, formate, pyruvate, hydrogen & Standard set & $0.1-5$ \\
\hline W3-6-1 & Lactate, formate, pyruvate, hydrogen & Standard set, Nitrate & $0.1-5$ \\
\hline W3-7-1 & Lactate, formate, pyruvate, hydrogen & Standard set & $0.1-5$ \\
\hline W3-7-2 & Lactate, formate, pyruvate, hydrogen & Standard set & $0.1-5$ \\
\hline W3-11-1 & Lactate, formate, pyruvate, hydrogen & Standard set & $0.1-5$ \\
\hline W3-11-2 & Lactate, formate, pyruvate, hydrogen & Standard set & $0.1-5$ \\
\hline W3-14-2 & Lactate, formate, pyruvate, hydrogen & Standard set & $0.1-5$ \\
\hline PV-4 & Lactate, formate, pyruvate, hydrogen & Standard set & $0.1-5$ \\
\hline PS-3 & Lactate, formate, pyruvate, hydrogen, glucose & Standard set, Nitrate & $1-3$ \\
\hline PS-5 & Lactate, formate, pyruvate, hydrogen & Standard set & $1-3$ \\
\hline PS-7 & Lactate, formate, pyruvate, hydrogen, glucose & Standard set, Nitrate & $1-3$ \\
\hline
\end{tabular}


The mineralogical composition of the transformed phases during microbial Fe(III) reduction was determined using X-ray diffraction (XRD; Zhang et al. 1997). Scanning electron microscopy (SEM) with energy dispersive X-ray analysis was also used for the analysis of morphology and mineralogy of the iron mineral phases formed by the isolates (Zhang et al. 1997). The akaganeite used in this study was prepared as described elsewhere (Roh et al. 2003).

\section{RESULTS}

\section{Sedimentary geochemical environment}

The greatest geochemical differences were observed between deep ocean and shallow stations. Dissolved $\mathrm{Mn}(\mathrm{II})$ concentrations were near the analytical detection limit throughout the sediment profile at the 3 shallowest stations from the coast of Washington State. Conversely, at these stations Fe(II) concentrations were low at the surface but all profiles exhibited a subsurface maximum that varied in concentration between 40 and $65 \mathrm{mM}$. At the deep ocean station the situation was reversed, with Fe(II) being near the limit of detection and Mn(II) showing the subsurface maximum. Fe(II) and Mn(II) profiles in the Puget Sound showed maxima at the same depth interval. Also, both $\mathrm{Mn}$ (II) and Fe(II) reached much higher concentrations in the Puget
Sound core. The peaks in the metal distributions were clearly due to reduction at those depths and subsequent diffusion both upward and downward Although sulfate reduction is active within microsites at all locations sampled, the sulfide produced is either quickly oxidized or precipitated as metal sulfides. Thus, free sulfide and highly reducing conditions are not observed in the sediment layers sampled (Hartnett \& Devol 2003).

Pore-water profiles of dissolved $\mathrm{O}_{2}, \mathrm{NO}_{3}$, and $\mathrm{NH}_{4}$ were very similar at all the stations from the coast of Washington State and in the Puget Sound, with some differences apparent in nitrate penetration at the deepest station (Fig. 1). No profiles were available for the vent sample due to the differences in sampling techniques employed at that site. Dissolved oxygen decreased rapidly within the sediments at all stations sampled. The shallowest penetration depth was about $0.5 \mathrm{~cm}$ at the shallowest station and the deepest penetration at the deepest station was about $1.8 \mathrm{~cm}$ (no oxygen data were available from the $997 \mathrm{~m}$ station). Similarly, nitrate decreased rapidly, and the nitrate penetration depth was indistinguishable from the oxygen penetration depth at all stations except at the deepest Washington coast station. There, the nitrate penetration depth (about $3.5 \mathrm{~cm}$ ) was approximately twice as deep as the oxygen penetration depth. At all stations, ammonium was low at the surface but accumulated to significant concentrations between 40 and $80 \mathrm{mM}$ at depth in the sediments.

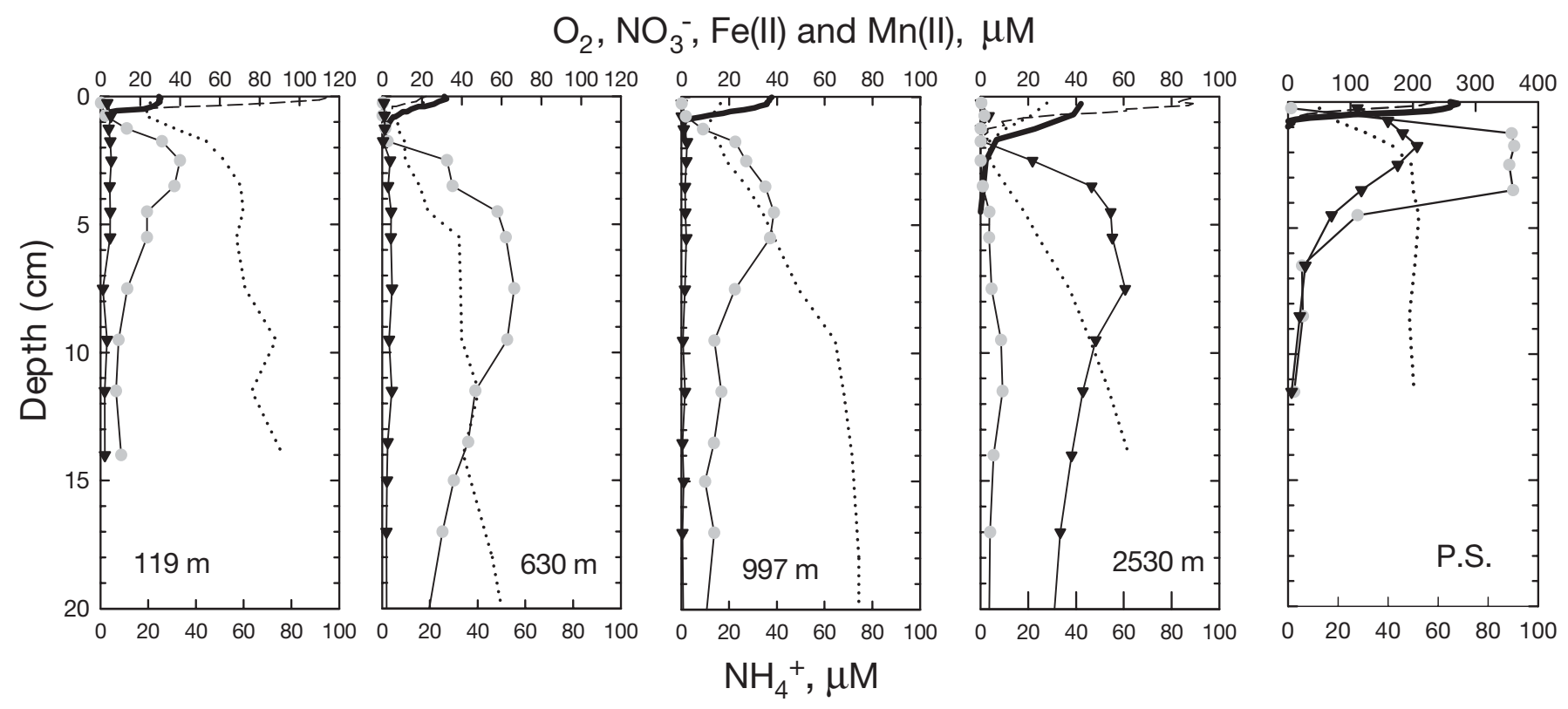

Fig. 1. Pore water chemistry, including $\mathrm{O}_{2}(---), \mathrm{NO}_{3}^{-}(-), \mathrm{Fe}(\mathrm{II})(\bullet), \mathrm{Mn}(\mathrm{II})(\boldsymbol{\nabla})$ and $\mathrm{NH}_{4}(\cdots \cdots)$, for Pacific Ocean and Puget Sound (P.S.) sediment sample stations. Depth: depth within the sample core. Pacific Ocean samples were collected at the following depths: Stn 301 at 119 m, Stn 306 at 630 m, Stn 307 at 997 m, and Stn 304 at 2530 m. The Puget Sound sample was collected at a depth of $220 \mathrm{~m}$ 


\section{Isolation and identification of bacteria}

Bacteria capable of coupling anaerobic growth at low temperatures typical of open ocean sediment environments with the utilization of various forms of Fe(III) and other metals were successfully recovered from the 3 marine environments (Table 1). They were all Gram negative, rod-shaped, facultative anaerobes that grew well either aerobically in the presence of oxygen or anaerobically coupled to the reduction of various metals. Studies of electron donor and electron acceptor utilization and of temperature and salinity limitations on metal reduction were done on all strains.

Maximum likelihood analysis of SSU rRNA gene sequences indicated that the isolates were all closely related to members of the well-studied facultativeanaerobe genus Shewanella (Fig. 2) and that location appeared to play a role in the group of Shewanella isolated. A similar topology for the phylogenetic tree was obtained with the neighbor-joining distance method (data not shown). One cluster of isolates from the coast of Washington State, consisting of W3-14-2, W3-4-1, W3-7-1, and W3-11-2, as well as PS-3, PS-5, and PS-7 from the Puget Sound, grouped closely to Shewanellae associated with reproductive glands of the Pacific Ocean squid Loligo pealei (Leonardo et al. 1999). Isolates W3-11-1 and W3-7-2 were 91 to $92 \%$ similar to the species Shewanella gelidimarina, a bacterium isolated from Antarctic Sea ice (Bowman et al. 1997). Isolate W3-6-1 was most closely related to $S$. oneidensis

Fig. 2. Phylogenetic comparison of bacterial isolates from marine samples with previously described members of the genus Shewanella
MR-1, showing a similarity of $98.4 \%$ (Ventkateswaren et al. 1999). PV-4 was found to be most similar to Shewanella algae BrY. However, based on a complete SSU gene sequence similarity of only $92 \%$ and the fact that it grows well at $4{ }^{\circ} \mathrm{C}, \mathrm{PV}-4$ may represent a novel species within the genus Shewanella. Detailed taxonomic studies will be required for confirmation.

\section{Utilization of electron acceptors and donors}

All isolated bacteria were able to utilize Co(III)EDTA, manganese oxide, and various forms of iron as electron acceptors for growth coupled to the oxidation of lactate under anaerobic conditions at $8^{\circ} \mathrm{C}$ (Table 2). All the isolates were able to use chelated forms of iron, including $\mathrm{Fe}(\mathrm{III})$-citrate and Fe(III)-EDTA, as well as poorly crystalline iron hydroxide as terminal electron acceptors. Iron reduction did not occur in anaerobic medium in the absence of the isolates with only the addition of the electron acceptors Fe(III)-citrate, Fe(III)-EDTA or amorphous iron. The organisms also did not reduce iron when the above forms of iron were supplemented with $10 \mathrm{mM}$ citrate, indicating that neither the chelate (citrate) nor the minimal amount of yeast extract present in the medium were able to serve as electron donors for growth. All isolates reduced brown, non-magnetic Fe(III) oxyhydroxides (akaganeite; FeOOH) to black magnetic minerals using lactate as an electron donor under a $\mathrm{N}_{2}$ or an $\mathrm{N}_{2} / \mathrm{CO}_{2}(80 / 20 \%)$ headspace. Magnetite was not formed in the absence of lactate. W3-6-1, PS-3, and PS-7 were capable of reducing nitrate but the other isolates were not (Table 2). PS-3 and PS-7 were able to couple the oxidation of $10 \mathrm{mM}$ glucose with the reduction of Fe(III) and the other isolates were not (Table 2). All of the isolates were able to use lactate, formate, pyruvate, and hydrogen as electron donors for Fe(III) reduction, with lactate and hydrogen producing the fastest rates of reduction. The Puget Sound isolates were also tested for the ability to use toluene and glycerol but could not use them as electron donors (Table 2).

Temperature limits for growth and salt requirements were similar for the 10 bacteria isolated from the coast of Washington State and from the Puget Sound, but not the vent isolate PV-4 (Tables 1 \& 2). The 
Puget Sound and Pacific Ocean isolates demonstrated the ability to grow at both 0 and $37^{\circ} \mathrm{C}$, with the temperature optimum falling between 14 and $20^{\circ} \mathrm{C}$. PV-4 exhibited a wider range of temperature tolerance, including exhibiting very good growth at $37^{\circ} \mathrm{C}$. The Puget Sound isolates required 1 to $3 \%$ for growth and iron reduction. In contrast, the isolates from the coast of Washington State and PV-4 grew and produced magnetite at 0.1 to $5 \%$ salt concentration. None of the isolates grew or produced iron at a salt concentration of $10 \%$.

\section{Detailed studies with W3-6-1 and PS-7}

Strains W3-6-1, isolated from deep Pacific Ocean marine sediments, and PS-7, isolated from Puget Sound, were evaluated for iron reduction coupled to hydrogen at $8^{\circ} \mathrm{C}$. Hydrogen was chosen for the detailed studies due to its environmental relevance as an electron donor in aquatic environments (Lovley 2001). Cell numbers increased over time in association with the reduction of $\mathrm{Fe}(\mathrm{III})$, which indicated that they obtained energy to support growth (Coates et al. 1996). No increase in cell numbers was observed in medium without the addition of the electron acceptor, indicating that growth was dependent on the presence of the supplemented metals. After 1 wk of incubation, Fe(II) concentration reached a level 19-fold or higher than controls without cells for both W3-6-1 (Fig. 3A) and PS7 (data not shown).

There is little information detailing the reduction of Co(III)-EDTA at low temperatures. Co(III)-EDTA reduction coupled to the oxidation of hydrogen was examined in W3-6-1 and PS-7. After $30 \mathrm{~h}$ at $8^{\circ} \mathrm{C}, \mathrm{Co}(\mathrm{II})$ reached a level approximately 16 -fold higher than controls for both W3-6-1 (Fig. 3B) and PS-7 (data not shown). Growth and Co(III) removal from solution appeared to be somewhat uncoupled (Fig. 3), perhaps due to more rapid uptake of cobalt by the bacteria than of reduction. W3-6-1 was also studied in greater detail to determine the effects of still lower temperature on the rate of Co(III)-EDTA reduction (Fig. 4) with hydrogen as the electron donor. Although rates were much slower that at $8^{\circ} \mathrm{C}$, at both $4^{\circ} \mathrm{C}$ (Fig. $4 \mathrm{~A}$ ) and $0^{\circ} \mathrm{C}$ (Fig. 4B), W3-6-1 was capable of substantial reduction of Co(III)-EDTA coupled to the production of new cells after $10 \mathrm{~d}$.

\section{Mineral formation}

W3-6-1 was able to reduce non-magnetic Fe(III) oxyhydroxides (akaganeite; FeOOH) to black magnetic minerals at a wide range of temperatures using
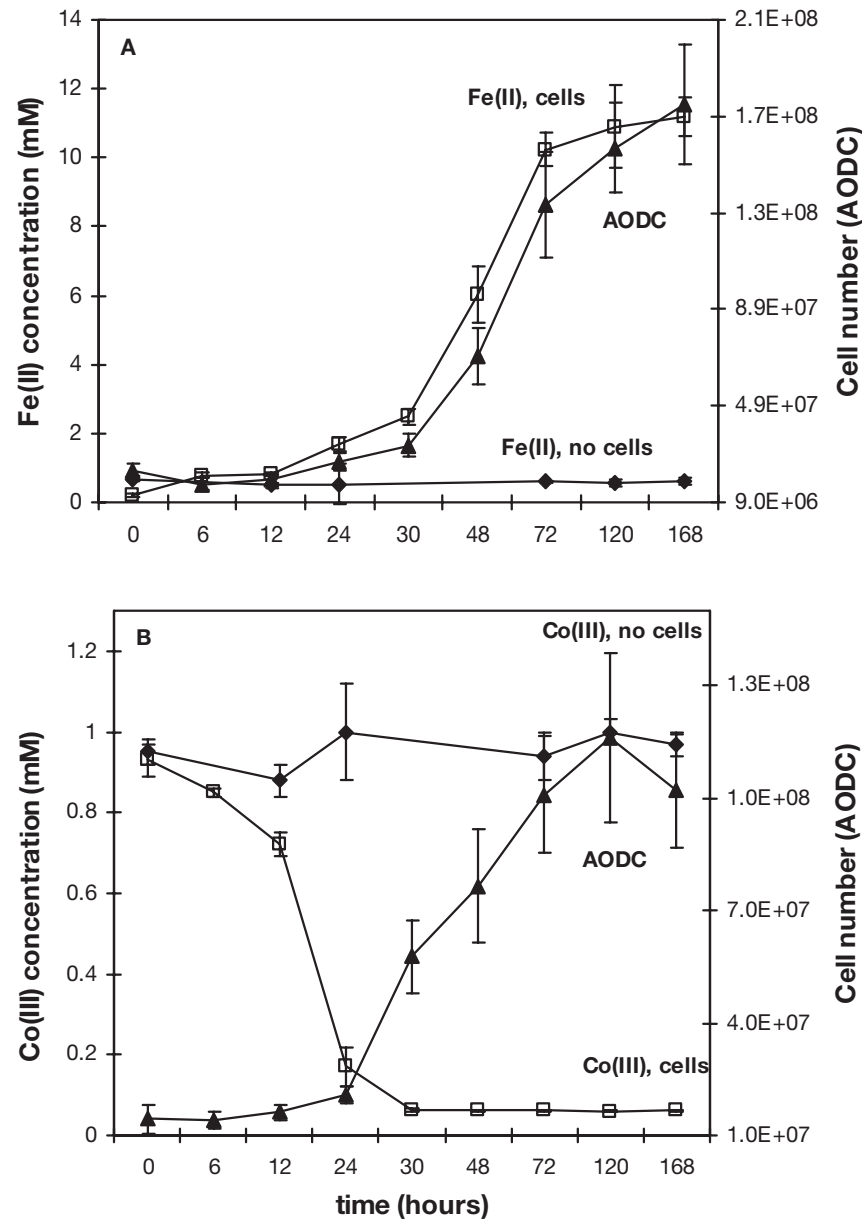

Fig. 3. Reduction of (A) ferric citrate and (B) Co(III)-EDTA at $8^{\circ} \mathrm{C}$ by W3-6-1. Results are the average of 3 replicate samples. Cell growth $(\mathbf{\Lambda})$ was evaluated in triplicate using acridine orange direct counts (AODC) and fluorescence microscopy. Fe(II) (with added cells: $\square$; without added cells: $\bullet$ ) was quantified in triplicate using the ferrozine method

either hydrogen or lactate as an electron donor under a $\mathrm{N}_{2}$ or $\mathrm{N}_{2} / \mathrm{CO}_{2}(80 / 20 \%)$ headspace. XRD analysis of the black magnetic minerals revealed that magnetite was mainly formed under a $\mathrm{N}_{2}$ headspace and a mixture of magnetite and siderite were formed under the $\mathrm{N}_{2} / \mathrm{CO}_{2}$ headspace after the microbial reduction of Fe(III) oxyhydroxide (e.g. Fig. 5). SEM with EDX (Energy Dispersive X-Ray Spectroscopy) analysis of iron minerals formed under a $\mathrm{N}_{2} / \mathrm{CO}_{2}$ headspace showed that siderite particles were disk-like or ballshaped crystals with diameters between 10 and $20 \mu \mathrm{m}$. The siderite crystals co-existed with microcrystalline magnetite crystals. Siderite formation did not occur when carbon dioxide was not included as a headspace gas. The magnetic minerals were not observed if the culture medium was not inoculated with the isolates. 

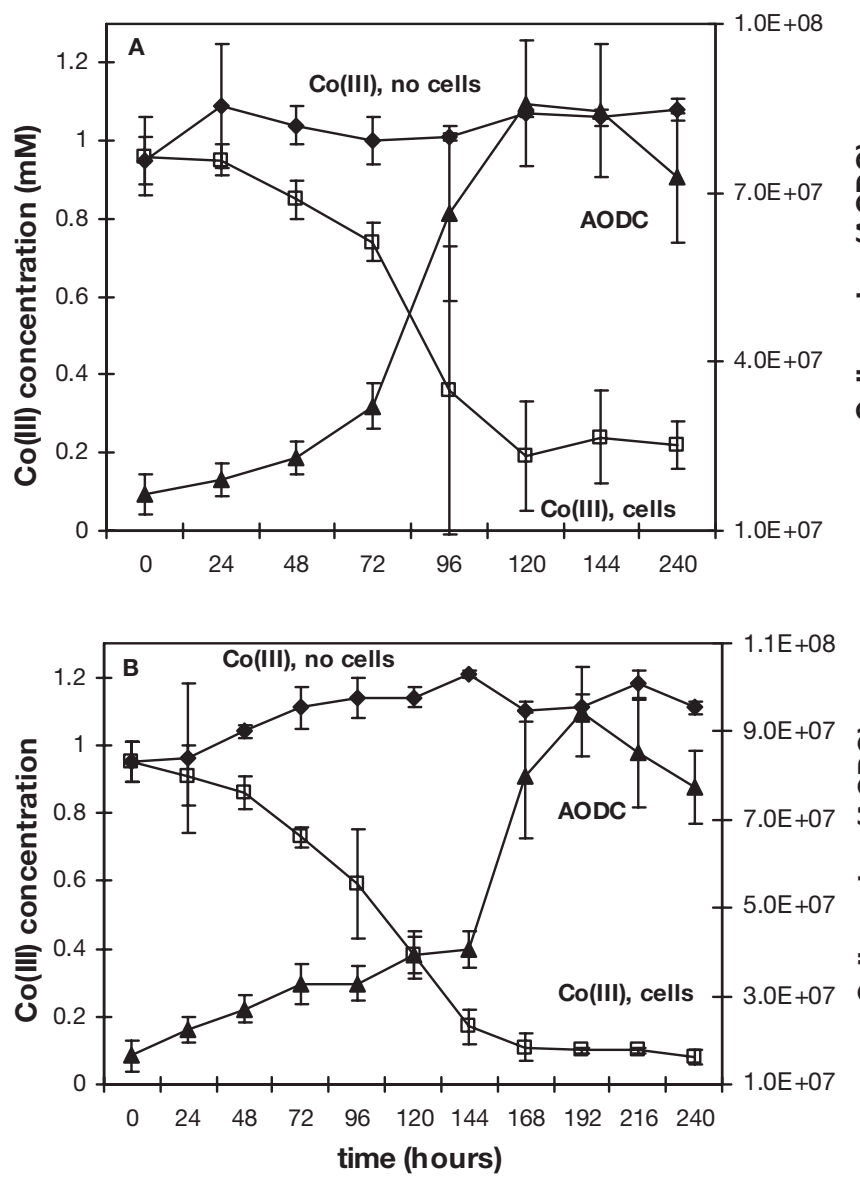

Fig. 4. Reduction of Co(III)-EDTA coupled to the oxidation of hydrogen by W3-6-1 at (A) $4^{\circ} \mathrm{C}$ and (B) $0^{\circ} \mathrm{C}$. Results are the average of 3 replicate samples. Cell growth $(\boldsymbol{\Lambda})$ was evaluated in triplicate using acridine orange direct counts (AODC) and fluorescence microscopy. Co(III) (with added cells: $\square$; without added cells: $\bullet$ ) was quantified in triplicate by spectroscopy

\section{DISCUSSION}

The geochemical profiles of the sample sites from which these strains were isolated confirm previous reports that sediment microorganisms participating in biogeochemical cycles remain active at low temperatures (Kostka et al. 1999). The sediment pore-water chemistry (e.g. absence of oxygen below the upper few $\mathrm{mm}$ and the peaks in the metal profiles at depth) indicates that the environments from which we isolated the bacteria represent active metal reduction zones. It is generally assumed that the various electron acceptors are used in their respective order of thermodynamic energy yield, $\mathrm{O}_{2}>\mathrm{NO}_{3}^{-}>\mathrm{MnO}_{2}>\mathrm{FeOOH}>\mathrm{SO}_{4}^{-}$ (Froelich et al. 1979, Luther et al. 1997). All sediments from the coast of Washington State and those from the Puget Sound show that oxygen and nitrate are consumed before metal reduction, higher up in the sedi- ment column, and that metal reduction follows. However, for the coast of Washington State samples, it is not totally obvious from the profiles that Mn(III,IV) is reduced before Fe(III) because in all but one of the profiles there is an Fe(II) peak with no Mn(II) peak above it. However, the lack of reduced manganese in the shallow Washington State stations is likely due to near complete reduction and mobilization out of the sediments of available manganese oxides as the unpublished data on solid-phase manganese suggests very low concentrations at the shallow water sites (Devol unpubl., J. W. Murray pers. comm.). Previous reports have indicated that microbial metal respiration influences not only the speciation of iron and manganese in anoxic marine sedimentary environments, but also the carbon cycle and the fate of a variety of trace metals and nutrients (Lovley 1993, 2001).

Although these isolates are closely related to previously described members of the genus Shewanella, they exhibited slightly different physiological growth patterns. In particular, growth on acetate and glucose while reducing iron, salt concentration, and maximum growth temperature provide useful physiological tests for separating species. Previous reports for S. putrefaciens, S. algae, S. frigidimarina, and S. gelidimarina (Bowman et al. 1997, Vogel et al. 1997) demonstrate their ability to utilize acetate as an electron donor in order to reduce ferric iron. Neither $S$. frigidimarina nor S. gelidimarina grow above $30^{\circ} \mathrm{C}$. Several, but not all, Shewanella species isolated from marine environments require salt for growth. S. pealeana, S. amazonensis, $S$ woodyi, and $S$. gelidimarina have optimal growth in medium containing at least $1 \%$ sodium chloride (Bowman et al. 1997, Makemson et al. 1997, Ventkateswaran et al. 1998, Leonardo et al. 1999). However, there have been reports of strains of $S$. algae and $S$. putrefaciens growing in salt concentrations ranging from 1 to $10 \%$ sodium chloride (Caccavo et al. 1992, Vogel et al. 1997). The recently described Shewanella species isolated from Antarctica, S. frigidimarina, was shown to not require sodium ions for growth, but was able to tolerate a maximum $\mathrm{NaCl}$ concentration of up to $8 \%$ (Bowman et al. 1997). The Puget Sound strains required 1 to $3 \% \mathrm{NaCl}$ for iron reduction, while the other strains did not. Of all the isolates, only PS-3 and PS-7 from the Puget Sound sediments are able to grow by coupling the oxidation of glucose to the reduction of ferric iron. Glucose utilization during iron respiration has been proposed to represent a novel mode of metabolism for the Shewanellae, but it is not widespread (Coates et al. 1998b).

Except for the vent isolate, the strains isolated are not distinguishable by growth temperature response. Since the optimum growth temperatures are above $15^{\circ} \mathrm{C}$ and strains grew well above $20^{\circ} \mathrm{C}$, these isolates 


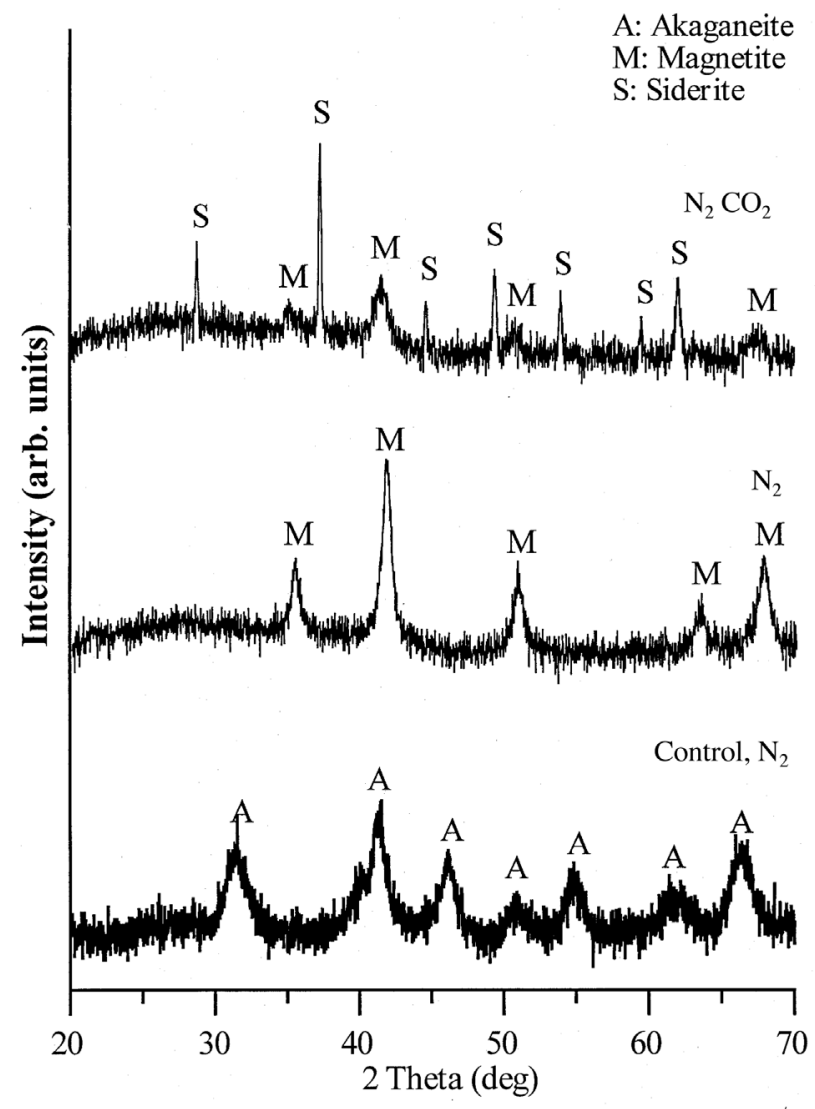

Fig. 5. Differences in X-ray diffraction (XRD) analysis of iron minerals formed by W3-6-1 at $18^{\circ} \mathrm{C}$ under a $\mathrm{N}_{2}$ and a $\mathrm{N}_{2} / \mathrm{CO}_{2}$ headspace

are classified as psychrotolerant according to the definition presented by Morita \& Moyer (2001). It is interesting that the optimum growth temperature for each isolate is above the in situ temperature of the environment from which it was recovered, indicating that these organisms have adapted to their current living conditions. Brettar et al. (2003) recently reported on the isolation of Idiomarina baltica, a marine bacterium from the Baltic Sea that demonstrated growth over a wide range of temperatures, with the optimum growth occurring between 20 and $44^{\circ} \mathrm{C}$. The higher temperature tolerance of PV-4 and its ability to reduce metal is interesting in view of its origin. The location near the vent may indicate that it originated in a higher temperature environment and was adapted to temperatures higher than the $4^{\circ} \mathrm{C}$ typical of marine bottom waters. Similarly, the mat may have been subject to temperature variations that would favor bacteria with a wide temperature tolerance. Temperatures measured at the vents with a thermistor probe from a submersible have been both higher than those in bottom waters and variable, dropping from $23^{\circ} \mathrm{C}$ in 1996 to $11^{\circ} \mathrm{C}$ in 1997 (when sample was collected) and $10^{\circ} \mathrm{C}$ in 1998 (Moyer unpubl. data). Hydrothermal vents are well known as centers of intense geochemical and biological extremes (Lutz et al. 1994, Duennebier et al. 1997, Sievert et al. 1999).

Several characteristics identified the Shewanella isolates described in this study as being useful low temperature models for studying the possible effects of metal reduction on pore-water chemistry and for examining mineral formation. The Shewanella isolates use a wide variety of electron acceptors such as oxygen, nitrate, and metals, and reduce various metals coupled to the oxidation of several organic acids and hydrogen at temperatures down to $0^{\circ} \mathrm{C}$. Results from W3-6-1 and PS-7 demonstrated that in pure culture microbial iron reduction at low temperatures (e.g. $8^{\circ} \mathrm{C}$ ) could occur at rates similar to mesophilic bacteria. Even though the experiments were conducted at $8^{\circ} \mathrm{C}$, the rate of $\mathrm{Fe}$ (II) evolution coupled to the oxidation of hydrogen demonstrated by W3-6-1 was very similar to those published for the well-studied mesophilic, metal-reducing Geobacter organisms (Coates et al. 1996) and the recently described thermophilic Thermus isolate (Kieft et al. 1999). W3-6-1 was also capable of iron reduction down to $0^{\circ} \mathrm{C}$ but at reduced rates.

Because the significance of $\mathrm{Co}(\mathrm{III})$ reduction in marine sediments remains unclear, the importance of the ability of these iron-reducing bacteria to reduce $\mathrm{Co}(\mathrm{III})$ is also uncertain. Cobalt is present at relatively low concentrations in marine systems water $\left(0.3 \mu \mathrm{g} \mathrm{I}^{-1}\right)$ and is most often in the form of $\mathrm{CoCl}_{2}, \mathrm{Co}(\mathrm{OH})_{2}$, or $\mathrm{CoO}$ (Richardson 1993). It is unlikely that Co(III) oxides represent a significant means of bacterial respiration during carbon oxidation. More likely, Co(III) reduction will impact the cycling of this trace element, which is an essential co-factor for cobalamine (vitamin B12). Although open ocean cobalt concentrations are very low, localized enrichments of $\mathrm{Co}(\mathrm{III})$ due to adsorption may be found associated with manganese oxides or ferromanganese nodules (Lee \& Tebo 1994, and references within). Bacterial reduction of insoluble $\mathrm{Co}(\mathrm{III})$ may release soluble $\mathrm{Co}(\mathrm{II})$, which can then be taken up by either micro- or macroorganisms living nearby. The practical importance of $\mathrm{Co}(\mathrm{III})$ reduction may lie in the terrestrial environment. ${ }^{60} \mathrm{Co}$ has been identified as a priority pollutant by the United States Department of Energy, and its migration in contaminated subsurface environments is influenced by the presence of chelating agents, as well as local mineralogy (Szecsody et al. 1994, Brooks et al. 1999). W3-6-1 indicates that the cobalt cycle should remain active at low temperatures, similar to iron cycling in marine sediments.

Metal reduction by the isolates resulted in formation of the minerals magnetite and siderite, depending on the presence of headspace $\mathrm{CO}_{2}$ (e.g. Figs. 5 \& 6). 
Microorganisms often directly and indirectly influence mineral formation. This magnetite formation indicates that dissimilatory iron-reducing bacteria may contribute to sediment magnetism by magnetite formation during anaerobic respiration (Karlin et al. 1987, Lovley et al. 1987). Our results are consistent with those of Fredrickson et al. (1998) and Roh et al. (2003), who found siderite formation by microbial iron reduction in high carbonate systems and minerals including magnetite under other conditions. The siderite globules formed by the these Fe(III)-reducing bacteria have a surface structure resembling flakes of crystals rather than a single rhombohedral crystal formed by Geobacter metallireducens (Mortimer \& Coleman 1997). Fredrickson et al. (1998) also show that pH has a strong influence on the minerals formed, and that presence of electron shuttles strongly influences rates of reduction. Although not presently common, formation of siderite in marine sediments may present a unique potential for the sequestration of $\mathrm{CO}_{2}$ (Postma 1981, Pye et al. 1990) in high iron environments or with the addition of iron.

Marine sediments represent sites of active biogeochemical processes. The microorganisms indigenous to these habitats are well adapted to their environment and continue to remain active at temperatures at or below $0^{\circ} \mathrm{C}$ (Kostka et al. 1999). We described bacteria isolated from 3 distinct marine habitats that were capable of reducing metals and forming minerals under cold-temperature conditions. W3-6-1 demonstrated that the reduction of iron and cobalt, as well as the formation of magnetite and siderite, could be studied in pure culture at temperatures as low as $0^{\circ} \mathrm{C}$. This serves well as a model for future investigations into the biogeochemisty of marine sediments.

Acknowledgements. This research was funded by The United States Department of Energy's Biotechnology InitiativeOcean Marine and Microbial Genome programs, and by the Laboratory Directed Research and Development Program through Oak Ridge National Laboratory. R.D.S. was supported by the Hollaender Distinguished Postdoctoral Fellow Program administered by Oak Ridge Institute for Science and Education and Oak Ridge Associated Universities. CobaltEDTA was kindly provided by Drs. P. Jardine and S. Brooks of Oak Ridge National Laboratory. Oak Ridge National Laboratory is managed by The University of Tennessee-Battelle LLC (limited liability company) for The United States Department of Energy under contract DE-AC05-00OR22725.

\section{LITERATURE CITED}

Aller RC, Hall POJ, Rude PD, Aller JY (1998) Biogeochemical heterogeneity and subtoxic diagenesis in hemipelagic sediments of the Panama Basin. Deep-Sea Res I 45: 133-165

Anderson L (1979) Simultaneous spectrophotometric determination of nitrate and nitrite by flow injection analysis. Anal Chim Acta 110:123-128
Bender M, Martin W, Hess J, Sayles F, Ball L, Lambert C (1987) A whole-core squeezer for interfacial pore-water sampling. Limnol Oceanogr 32:1214-1225

Bowman JP, McCammon SA, Nichols DS, Skerratt JH, Rea AM, Nichols PD, McMeekin TA (1997) Shewanella gelidimarina sp. nov. and Shewanella fridimarina sp. nov., novel Antarctic species with the ability to produce eiosapentanoic acid and grow anaerobically by dissimilatory Fe(III) reduction. Int J Syst Bacteriol 47:1040-1047

Bowman JP, Rea SM, McCammon SA, McMeekin TA (2000) Diversity and community structure within anoxic sediment from marine salinity meromectic lakes and a coastal meromectic marine basin, Vestford Hilds, Eastern Antarctica. Environ Microbiol 2:227-237

Brandes JA, Devol AH (1995) Simultaneous oxygen and nitrate respiration in coastal sediments: evidence for discrete diagenesis. J Mar Res 52:771-797

Brettar I, Christen R, Höfle (2002) Shewanella denitrificans sp. nov., a vigorously denitrifying bacterium isolated from the oxic-anoxic interface of the Gotland Deep in the central Baltic Sea. Int J Syst Evol Microbiol 52:2211-2217

Brettar I, Christen R, Höfle (2003) Idiomarina baltica sp. nov., a marine bacterium with a high optimum growth temperature isolated from surface water of the central Baltic Sea. Int J Syst Evol Microbiol 53:407-413

Brewer PB, Spencer DW (1974) Colorimetric determination of manganese in anoxic waters. Limnol Oceanogr 14: 450-454

Brooks SC, Carroll SL, Jardine PM (1999) Sustained bacterial reduction of CoIIIEDTA in the presence of competing geochemicl oxidation during dynamic flow. Environ Sci Technol 33:3002-3011

Caccavo R, Blakemore RP, Lovley DR (1992) A hydrogenoxidizing, Fe(III)-reducing microorganism from the Great Bay Estuary, New Hampshire. Appl Environ Microbiol 58: 3211-3216

Canfield DE, Jorgensen BB, Fossing H, Glud R and 6 others (1993) Pathways of organic carbon oxidation in three continental margin sediments. Mar Geol 113:27-40

Coates JD, Lonergan DJ, Jenter H, Lovley DR (1996) Isolation of Geobacter species from diverse sedimentary environments. Appl Environ Microbiol 62:1531-1536

Coates JD, Ellis DJ, Blunt-Harris EL, Gaw CV, Roden EE, Lovley DR (1998a) Recovery of humic acid-reducing bacteria from a diversity of environments. Appl Environ Microbiol 64:1504-1509

Coates JD, Councell T, Ellis DJ, Lovley DR (1998b) Carbohydrate oxidation coupled to Fe(III) reduction, a novel form of microbial respiration. Anaerobe 4:277-282

de Bruijn FJ (1992) Use of repetitive (repetitive extragenic palindromic and enterobacterial repetitive intergeneric consensus) sequences and the polymerase chain reaction to fingerprint the genomes of Rhizobium meliloti isolates and other soil bacteria. Appl Environ Microbiol 58: 2180-2187

Devol AH, Christensen JP (1993) Benthic fluxes of nitrogen cycling in sediments of the continental margin of the eastern North Pacific. J Mar Res 51:345-372

Duennebier FK, Becker NC, Caplan-Auerbach J, Clague DA and 18 others (1997) Researchers rapidly respond to submarine activity at Loihi volcano, Hawaii. EOS Trans Am Geophys Union 78:229-233

Emerson D, Moyer CL (2002) Neutrophilic Fe-oxidizing bacteria are abundant at the Loihi seamount hydrothermal vents and play a major role in Fe oxide deposition. Appl Environ Microbiol 68:3085-3093

Fredrickson JK, Zachara JM, Kennedy DW, Dong H, Onstott 
TC, Hinman NW, Li SM (1998) Biogenic iron mineralization accompanying the dissimilatory reduction of hydrous ferric oxide by a groundwater bacterium. Geochim Cosmochim Acta 62:3239-3257

Froelich PN, Klinkhammer GP, Bender ML, Luedtke NA and 6 others (1979) Early oxidation of organic matter in pelagic sediments of the equatorial Atlantic: suboxic diagenesis. Geochim Cosmochim Acta 43:1075-1090

Hartnett HE, Devol AH (2003) The role of a strong oxygen in the preservation and degradation of organic matter: a carbon budget for the continental margins of NW Mexico and Washington. Geochim Cosmochim Acta 67:247-264

Hobbie JE, Daley RJ, Jasper S (1977) Use of nucleopore filters for counting bacteria by fluorescence microscopy. Appl Environ Microbiol 33:1225-1228

Hungate RE (1969) A roll tube method for cultivation of strict anaerobes. Methods Microbiol 3B:117-132

Irwin JA, Alfredsson GA, Lanzetti AJ, Gudmundsson HM, Engel PC (2001a) Purification and characterization of a serine peptidase from marine psychrophile strain PA-43. FEMS Microbiol Lett 201:285-290

Irwin JA, Gudmundsson HM, Marteinsson VT, Hreggvidsson GO, Lanzetti AJ, Alfredsson GA, Engel PC (2001b) Characterization of alanine and malate dehydrogenases from a marine psychrophile strain PA-43. Extremophiles 5: 199-211

Karlin R, Lyle M, Heath GR (1987) Authigenic magnetite formation in suboxic marine sediments. Nature 326:490-493

Kato C, Nogi Y (2001) Correlation between phylogenetic structure and function: examples from deep-sea Shewanella. FEMS Microbiol Ecol 35:223-230

Kieft TL, Fredrickson JK, Onstott TC, Gorby YA and 7 others (1999) Dissimilatory reduction of Fe(III) and other electron acceptors by a Thermus isolate. Appl Environ Microbiol 65:1214-1221

Kostka JE, Nealson KH (1995) Dissolution and reduction of magnetite by bacteria. Environ Sci Technol 29:2535-2540

Kostka JE, Thamdrup B, Glud RN, Canfield DE (1999) Rates and pathways of carbon oxidation in permanently cold arctic sediments. Mar Ecol Prog Ser 180:7-21

Lee Y, Tebo BM (1994) Cobalt (II) oxidation by the marine manganese (II)-oxidizing Bacillus sp. strain SG-1. Appl Environ Microbiol 60:2949-2957

Leonardo MR, Moser DP, Barbieri E, Branter CA, MacGregor BJ, Paster BJ, Stackebrandt E, Nealson KH (1999) Shewanella pealeana, sp. nov., a member of the microbial community associated with the accessory nidamental gland of the squid Loligo pealei. Int J Syst Bacteriol 49:1341-1351

Lovley DR (1993) Dissimilatory metal reduction. Annu Rev Microbiol 47:263-290

Lovley DR (2001) Dissimilatory Fe(III) reduction and Mn(IV) reduction. Micriobiol Rev 55:259-287

Lovley DR, Phillips EJP (1986) Organic matter mineralization with reduction of ferric iron in anaerobic sediments. Appl Environ Microbiol 55:700-706

Lovley DR, EJP Phillips (1988) Novel mode of microbial energy metabolism: organic carbon oxidation coupled to dissimilatory reduction of iron or manganese. Appl Environ Microbiol 54:1472-1480

Lovley DR, Stolz JF, Nord GL Jr, Phillips EJP (1987) Anaerobic production of magnetite by a dissimilatory iron reducing microorganism. Nature 330:252-254

Luther GWI, Sundby B, Lewis BL, Brendel PJ, Silverberg N (1997) Interactions of manganese with the nitrogen cycle: alternative pathways to dinitrogen. Geochim Cosmochim Acta 61:4043-4054

Lutz RA, Shank TM, Fornari DJ, Haymon RM, Lilly MD, Von
Damm KL, Desbruyeres D (1994) Rapid growth at deepsea hydrothermal vents. Nature 371:663-664

Makemson JC, Fulayfil NR, Landry W, Van Ert LM, Wimpee CF, Widder EA, Case JF (1997) Shewanells woodyi sp. nov., an exclusively respiratory luminous bacterium isolated from the Alboran Sea. Int J Syst Bacteriol 47:1034-1039

Miller TL, Wolin MJ (1974) A serum bottle modification of the Hungate technique for cultivating obligate anaerobes. Appl Microbiol 27:985-987

Morita RY, Moyer CL (2001) Origin of psychrophiles. In: Levin SA, Colwell R, Dailey G, Lubchenco J, Mooney HA, Schulze ED, Tilman GD (eds) Encyclopedia of biodiversity, Vol 4. Academic Press, San Diego, p 917-924

Mortimer RJG, Coleman ML (1997) Microbial influence on the oxygen isotopic composition of diagenetic siderite. Geochim Cosmochim Acta 61:1705-1711

Nealson KH, Saffarini D (1994) Iron and manganese in anaerobic respiration: environmental significance, physiology, and regulation. Annu Rev Microbiol 48:311-343

Perry KA, Kostka JE, Luther GW, Nealson KH (1993) Mediation of sulfur speciation by a Black Sea facultative anaerobe. Science 259:801-803

Phelps TJ, Raione EG, White DC, Fliermans CB (1989) Microbial activities in deep subsurface environments. Geomicrobiol J 7:79-91

Postma D (1981) Formation of siderite and vivianite and the pore-water composition of a recent bog sediment in Denmark. Chem Geol 31:225-224

Prescott LM, Harley JP, Klein DA (1990) Microbiology. William C. Publishers, Dubuque, IA

Pye K, Dickson AD, Schiavan N, Coleman ML, Cox M (1990) Formation of siderite-Mg-calcite-iron sulfide concretions in intertidal marsh and sandflat sediments, north Norfolk, England. Sedimentology 37:325-343

Richardson ML (ed) (1993) The dictionary of substances and their effects, Vol 2, Chap 357. Royal Society of Chemistry, Cambridge

Roh Y, Zhang CL, Vali H, Lauf RJ, Zhou J, Phelps TJ (2003) Chemical and environmental factors on iron biomineralization: magnetite and siderite formation. Clays Clay Minerals 51:83-95

Sievert SM, Brinkoff T, Muyzer G, Ziebis W, Kuever J (1999) Spatial heterogeneity of bacterial populations along an environmental gradient at a shallow submarine hydrothermal vent near Milos Island (Greece). Appl Environ Microbiol 65:3834-3842

Smith SW, Overbeek R, Woese C, Gilbert W, Gillevet PM (1994) The genetic data environment: an expandable GUI for multiple sequence analysis. Comput Appl Biosci 10: 671-675

Sørensen J (1982) Reduction of ferric iron in anaerobic, marine sediment and interaction with reduction of nitrate and sulfate. Appl Environ Microbiol 43:319-324

Strunk O, Gross O, Reichel B, May M and 10 others (1996) ARB - a software environment for sequence data. Department of Microbiology, Technical University of Munich (also available at: http:/www.mikro.biologie.tu-muenchen.de)

Szecsody JE, Zachara JM, Bruckhart PL (1994) Adsorptiondissolution reactions affecting the distribution and stability of Co(II)EDTA in iron oxide-coated sand. Environ Sci Technol 28:1706-1716

Thamdrup B, Rossello-Mora R, Amann R (2000) Microbial manganese and sulfate reduction in Black Sea shelf sediments. Appl Environ Microbiol 66:2888-2897

Venkateswaran H, Dollhopf ME, Aller R, Stackebrandt E, Nealson KH (1998) Shewanella amazonensis sp. nov., a novel metal-reducing facultative anaerobe from Amazon- 
ian shelf muds. Int J Syst Bacteriol 48:965-972

Venkateswaran H, Moser DP, Dollhopf ME, Lies DP and 9 others (1999) Polyphasic taxonomy of the genus Shewanella and description of Shewanella oneidensis sp. nov. Int J Syst Bacteriol 49:705-724

Vogel BF, Jorgensen K, Christensen H, Olsen JE, Gram L (1997) Differentiation of Shewanella putrefaciens and Shewanella alga on the basis of whole-cell protein profiles, ribotyping, phenotypic characterization, and 16S rRNA gene sequence analysis. Appl Environ Microbiol 63: 2189-2199

Weisburg WG, Barns SM, Pelletier DA, Lane DJ (1991) 16S ribosomal DNA amplification for phylogenetic study. J Bacteriol 173:697-703

Zhang CL, Liu S, Logan J, Mazumder R, Phelps TJ (1996) Enhancement of $\mathrm{Fe}(\mathrm{III}), \mathrm{Co}(\mathrm{III})$, and $\mathrm{Cr}(\mathrm{VI})$ reduction at elevated temperatures and by a thermophilic bacterium. Appl Biochem Biotechnol 57/58:923-932

Zhang CL, Liu S, Phelps TJ, Cole DR, Horita J, Fortier SM,

Editorial responsibility: Jed Fuhrman,

Los Angeles, California, USA
Elless MP, Valley JW (1997) Physiochemical, mineralogi$\mathrm{cal}$, and isotopic characterization of magnetite-rich iron oxides formed by thermophilic iron reducing bacteria. Geochim Cosmochim Acta 61:4621-4632

Zhang CL, Stapleton RD, Zhou JZ, Palumbo AV, Phelps TJ (1999) Iron reduction by psychrophilic enrichment cultures. FEMS Microbiol Ecol 30:367-371

Zhou JZ, Fries MR, Chee-Sanford JC, Tiejde JM (1995) Phylogenetic analyses of a new group of denitrifiers capable of anaerobic growth on toluene and description of Azoarcus tolulyticus sp. nov. Int J Syst Bacteriol 45:500-506

Zhou JZ, Davey ME, Figueras JB, Rivkina E, Gilichinsky D, Tiedje JM (1997) Phylogenetic diversity of a bacterial community determined from Siberia tundra soil DNA. Microbiology 143:3913-3919

Zhou JZ, Liu S, Xia B, Zhang C, Palumbo AV, Phelps TJ (2001) Molecular characterization of thermophilic iron-reducing enrichment cultures from deep subsurface environments. J Appl Microbiol 90:96-105

Submitted: February 15, 2003; Accepted: June 28, 2004 Proofs received from author(s): January 13, 2005 